\title{
PERANCANGAN EXTERNAL LIGHTNING PROTECTION GEDUNG DI KOMPLEK PLTG GORONTALO 100 MW DENGAN METODE ROLLING SPHERE, PROTECTION ANGLE, DAN COLLECTING VOLUME
}

\author{
Muhamad Marin Bakhtiar, Agung Warsito, and Abdul Syakur \\ Departemen Teknik Elektro, Fakultas Teknik, Universitas Diponegoro \\ Jl. Prof. Sudharto, SH, Kampus UNDIP Tembalang, Semarang 50275, Indonesia \\ ${ }^{*}$ E-mail: marinbakhtiar@gmail.com
}

\begin{abstract}
Abstrak
Menurut Badan Meteorologi Klimatologi dan Geofisika tingkat hari guruh pertahun di Indonesia adalah 25 sampai 200. Ini menunjukkan kecenderungan jumlah sambaran petir yang tinggi. Sambaran petir dapat merusak peralatan, merusak bangunan, bahkan korban jiwa. Hal tersebut menimbulkan kerugian yang sangat besar, sehingga dibutuhkan usaha untuk mengurangi resiko kerusakan, yaitu dengan Sistem Proteksi Petir (SPP). Gedung di komplek PLTG Gorontalo 100 MW belum memiliki SPP padahal Gorontalo memiliki hari guruh pertahun mencapai 175,2. Maka, digunakan SPP eksternal (External lightning protection) untuk melindungi gedung dari sambaran petir langsung dengan metode Rolling Sphere, Protection Angle, dan Collecting Volume. Dengan metode tersebut, kita dapat menentukan letak dan jumlah air terminal, down conductor, grounding rod pada tiap gedung hingga seluruh bagian gedung dapat terlindungi dari sambaran petir. Perhitungan dan perancangan Rolling Sphere dan Protection Angle yang digunakan berdasarkan IEC 62305-3 sedangkan Collecting Volume berdasarkan IEEE998-2012 standard. Dari penelitian ini dapat diketahui metode Collecting Volume memiliki area perlindungan terluas dan juga membutuhkan air terminal paling sedikit dibanding dengan metode lainnya. Sehingga, metode Collecting Volume merupakan SPP eksternal terbaik yang dapat melindungi gedung di komplek PLTG Gorontalo $100 \mathrm{MW}$ dari sabaran petir secara langsung.
\end{abstract}

Kata kunci: Petir, Sistem Proteksi Petir, Rolling Sphere, Protection Angle, Collecting Volume

\begin{abstract}
According to the Meteorology and Geophysics Departement days of thunder per year rate in Indonesia is 25 to 200. This range shows the trend in the number of lightning strikes is high. Lightning strikes can damage to equipment, damage to buildings, and even fatalities. It would have been causing huge losses, so it takes effort to reduce the risk of damage from lightning strikes with Lightning Protection System (LPS). Gorontalo gas power plant $100 \mathrm{MW}$ buildings have not installed LPS whereas Gorontalo has reached 175,2 days of thunder. Then, use external LPS to protect the buildings from a direct lightning strike with Rolling Sphere metohod, Protection Angle method, and Collecting Volume method. With this methods, we can determine the location and amount of each buliding air terminal, down conductor and grounding rod until the entire area can be protected from lightning strikes. Calculation and design of Rolling Sphere metohod, Protection Angle method by IEC 62305-3 Standard and Collecting Volume method by IEEE998-2012 standard. Collecting Volume method has the most extensive area protection than others. Collecting Volume method require the least air terminal than others. Thus, Collecting Volume method is the best method of external lightning protection system which can protect Gorontalo gas power plant $100 \mathrm{MW}$ buildings from direct lightning strike.
\end{abstract}

Keywords: Lightning, Lightning Protection System, Rolling Sphere, Protection Angle, Collecting Volume

\section{Pendahuluan}

Petir merupakan fenomena alam dimana terjadi loncatan muatan listrik antara awan dengan bumi karena perbedaan potensial antara awan dengan bumi yang besar. [1] Indonesia memiliki intensitas sambaran petir yang sangat tinggi. Hal ini didukung oleh letak Indonesia yang berada di kawasan tropis sehingga memiliki tingkat kelembaban dan pemanasan yang tinggi.[2] Sementara berdasarkan data Badan metorologi, klimatologi dan geofisika Sulawesi Utara pada kisaran tahun 2000-2008, Gorontalo memiliki Isokeraunik Level (IKL) sebesar $48 \%$ yang tergolong tinggi dan sangat dianjurkan untuk dipasang proteksi petir. [3] Sambaran langsung dapat menyebabkan kerusakan pada bangunan, peralatan, bahkan korban jiwa.[4] Sedangkan, tegangan lebih induksi yang disebabkan 
sambaran petir tidak langsung dapat mempengaruhi kinerja, bahkan kerusakan peralatan. Hal tersebut dapat menimbulkan kerugian yang sangat besar, sehingga dibutuhkan usaha untuk mengurangi resiko kerusakan akibat sambaran petir terlebih untuk bangunan penting, yaitu dengan sistem proteksi petir eksternal.[5]

Sistem protesi petir eksternal (external lightning protection) dipasang pada gedung di komplek PLTG Gorontalo 100 MW untuk meminimalisir terjadinya gangguan dan kerugian akibat sambaran petir. Perancangan proteksi petir ini dilakukan dengan menggunakan metode Rolling Sphere, Protection Angle dan Collecting Volume.

\section{Metode}

\subsection{Langkah Penelitian}

Gambar 1 menunjukan diagram alir perancangan external lightning protection gedung di komplek PLTG Gorontalo $100 \mathrm{MW}$ dengan metode rolling sphere, protection angle, dan collecting volume.

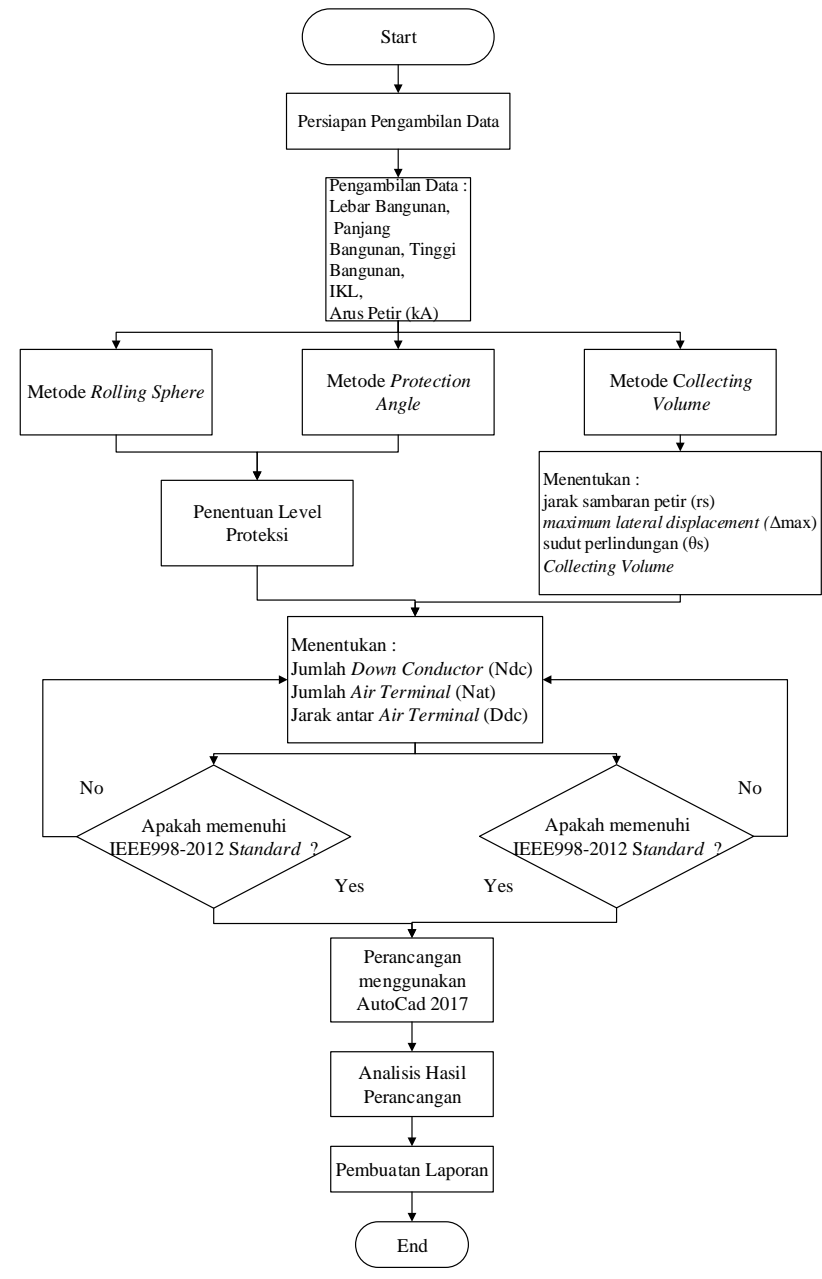

Gambar 1. Diagram Alir Langkah Penelitian

\subsection{Pengumpulan Data}

Data-data teknis penelitian diperoleh dari PT. Rekayasa Engineering Jakarta Selatan, JADPEN dan BMKG Sulawesi Utara. Data tersebut meliputi data karakteristik bangunan di komplek PLTG Gorontalo $100 \mathrm{MW}$, dan data karakteristik petir Gorontalo.

Tabel 1. Data Existing Bangunan

\begin{tabular}{|c|c|c|c|c|c|c|}
\hline Bangunan & $\begin{array}{l}\text { Panjang } \\
\text { (m) }\end{array}$ & $\begin{array}{l}\text { Lebar } \\
\text { (m) }\end{array}$ & $\begin{array}{l}\text { Tinggi } \\
\text { (m) }\end{array}$ & $\begin{array}{l}\text { IKL } \\
(\%)\end{array}$ & $\begin{array}{l}\text { Arus } \\
\text { Petir } \\
\text { (kA) }\end{array}$ & $\begin{array}{l}\text { Tinggi air } \\
\text { terminal } \\
\text { (m) }\end{array}$ \\
\hline $\begin{array}{l}\text { Gedung } \\
\text { Administrasi }\end{array}$ & 21 & 20.17 & 4.3 & 48 & $18-50$ & $1^{*}$ \\
\hline Masjid & 12.6 & 11.6 & 9.879 & 48 & $18-50$ & $1^{*}$ \\
\hline Gudang & 24 & 12 & 8.313 & 48 & $18-50$ & $1^{*}$ \\
\hline
\end{tabular}

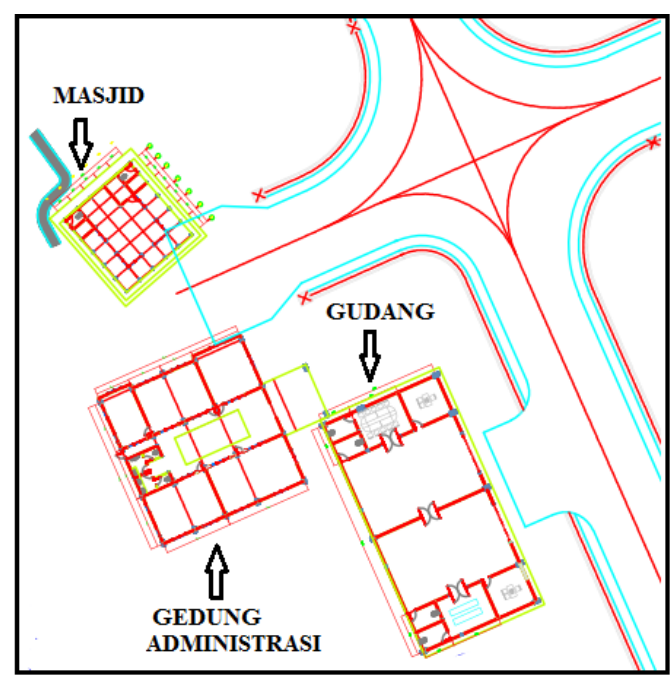

Gambar 2. Denah Lokasi

\subsection{Penentuan Taksiran Risiko}

Perhitungan taksiran risiko dipakai untuk menentukan level proteksi yang harus dipakai pada metode rolling sphere dan protection angle.[7]

$I K L=\frac{T d}{365} \times 100 \%$

$N g=0,04 \cdot T_{d}^{1,26}$

Dimana,

$\mathrm{Ng}=$ Kerapatan sambaran petir ke tanah (sambaran $/ \mathrm{Km}^{2} /$ tahun )

$\mathrm{T}_{\mathrm{d}} \quad=$ Hari guruh rata-rata pertahun

$N d=N g \cdot A e \cdot 10^{-6}$

Dimana,

$\mathrm{Nd}=$ Frekuensi sambaran petir langsung per tahun $\mathrm{Nc}$ $A e=a b+6 h(a+b)+9 . \pi h^{2}$ 
Dimana,

a $\quad=$ Panjang atap gedung $(\mathrm{m})$

$\mathrm{b}=$ Lebar atap gedung $(\mathrm{m})$

$\mathrm{h} \quad=$ Tinggi atap gedung $(\mathrm{m})$

Ae $=$ Area Cakupan dari Struktur $\left(\mathrm{m}^{2}\right)$

Pengambilan keputusan perlu atau tidaknya memasang sistem proteksi dilakukan dengan ketentuan sebagai berikut :

- Jika $\mathrm{Nd} \leq \mathrm{Nc}$ tidak perlu sistem proteksi petir.

- Jika Nd > Nc diperlukan sistem proteksi petir.

Penentuan tingkat proteksi petir dilakukan berdasakan nilai efisiensi sebagai berikut :

$$
E \geq 1-\frac{N c}{N d}
$$

Dimana,

$$
\begin{array}{ll}
\mathrm{E} & =\text { Efisiensi sistem proteksi petir. } \\
\mathrm{Nc} & =\text { Frekuensi sambaran petir tahunan yang } \\
& \text { diperbolehkan }\left(10^{-1}\right) . \\
\mathrm{Nd} & =\text { Frekuensi sambaran petir langsung per tahun }
\end{array}
$$

Tabel 2. Efisiensi Sistem Proteksi Petir (SPP)

\begin{tabular}{cc}
\hline $\begin{array}{c}\text { Class of Lightning Protection } \\
\text { Level (LPS) }\end{array}$ & $\begin{array}{c}\text { Efisiensi SPP (E) } \\
(\%)\end{array}$ \\
\hline I & 98 \\
III & 95 \\
IV & 90 \\
\hline
\end{tabular}

\subsection{Pengolahan Data}

Pengolahan data dilakukan dengan menghitung jumlah air terminal, jarak antar air terminal, jumlah down conductor, dan jarak down conductor dengan metode rolling sphere, protection angle berdasarkan IEC 62305-3 serta dengan metode collecting volume berdasarkan IEEE998-2012 standard.

\subsection{Perancangan Penempatan External Lightning Protection}

Hasil pegolahan data kemudian dijadikan sebagai acuan dalam perancangan penempatan external lightning protection gedung di komplek PLTG Gorontalo $100 \mathrm{MW}$. Perancangan dilakukan menggunakan perangkat lunak AutoCad 2017 dengan menggambarkan area proteksi petir pada gedung berdasarkan metode rolling sphere, protection angle dan collecting volume.

\subsection{Perbandingan Metode Rolling Sphere, Protection Angle, dan Collecting Volume}

Setelah merancang external lightning protection gedung di komplek PLTG Gorontalo $100 \mathrm{MW}$ menggunakan metode rolling sphere, protection angle, dan collecting volume. Selanjutnya, melakukan perbandingan hasil dari ketiga metode tersebut, berdasarkan luas area perlindungan dan jumlah air terminal yang digunakan pada metode tersebut dalam perancangan external lightning protection.

\section{Hasil dan Analisa \\ 3.1. Penentuan Taksiran Risiko}

Perhitungan diawali dengan menghitung taksiran resiko untuk menentukan level proteksi yang harus dipakai pada metode rolling sphere dan protection angle.[7]

Tabel 3. Hasil Perhitungan Taksiran Resiko

\begin{tabular}{lcccccc}
\hline \multicolumn{1}{c}{ Bangunan } & Td & Ng & $\mathbf{A e}\left(\mathbf{m}^{2}\right)$ & Nd & Nc & $\mathbf{E}(\%)$ \\
\hline Masjid & 175,2 & 26,84 & 4338,61 & 0,116 & 0,1 & 13,8 \\
Gudang & 175,2 & 26,84 & 4036,54 & 0,108 & 0,1 & 7,4 \\
Gedung & 175,2 & 26,84 & 2008,28 & 0,054 & 0,1 & - \\
Administrasi & & & & & & \\
\hline
\end{tabular}

Dari tabel 3 diketahui nilai Nd gedung administrasi $\leq \mathrm{Nc}$ sehingga tidak memerlukan SPP. Namun, dengan pertimbangan pentingnya gedung administrasi untuk menyimpan berkas dan arsip penting, maka gedung administrasi perlu diberi SPP. Sedangkan masjid dan gudang memiliki $\mathrm{Nd}>\mathrm{Nc}$ sehingga memerlukan SPP. Masjid memiliki efisiensi $13,8 \%$ dan gudang $7,4 \%$ sehingga berdasarkan ketentuan tabel 2, masjid dan gudang membutuhkan sistem proteksi level IV. Namun, dengan pertimbangan masjid merupakan gedung tertinggi yang ada di komplek dan banyaknya peralatan penting PLTG yang tersimpan dalam gudang, serta resiko terjadinya efek sambaraan tidak langsung bagi gedung-gedung lain yang dapat mengganggu dalam proses pembangkitan listrik PLTG Gorontalo $100 \mathrm{MW}$, maka dipilih efisiensi 90\% atau proteksi level III. Sehingga, semua gedung di komplek PLTG Gorontalo 100 MW menggunakan SPP level III pada metode rolling sphere dan protection angle.

\subsection{Perancangan external lightning protection dengan metode Rolling Sphere}

Dari hasil perhitungan didapat jumlah air terminal dan down conductor yang dipasang pada gedung di komplek PLTG Gorontalo $100 \mathrm{MW}$ adalah sebagai berikut :

Tabel 4. Hasil Perhitungan dengan Metode Rolling Sphere

\begin{tabular}{lllllll}
\hline Bangunan & $\mathbf{p}(\mathbf{m})$ & $\begin{array}{l}\mathbf{d}_{\operatorname{maxAT}} \\
(\mathbf{m})\end{array}$ & $\mathbf{N}_{\mathrm{DC}}$ & $\mathbf{d}_{\mathrm{DC}}(\mathbf{m})$ & $\mathbf{N}_{\mathrm{AT}}$ & $\begin{array}{l}\mathbf{d}_{\mathrm{AT}} \\
(\mathbf{m})\end{array}$ \\
\hline Masjid & 0,07 & 13,34 & 4 & 15 & 4 & 12,6 \\
$\begin{array}{l}\text { Gudang } \\
\text { Gedung }\end{array}$ & 0,06 & 13,34 & 5 & 15 & 6 & 12 \\
Administrasi & 0,058 & 13,34 & 6 & 15 & 9 & 10,5 \\
\hline
\end{tabular}

Keterangan :

$\mathrm{N}_{\mathrm{DC}} \quad$ : jumlah down conductor total

$\mathrm{N}_{\mathrm{AT}} \quad$ : jumlah air terminal total

$d_{D C} \quad$ : jarak antar down conductor

$d_{A T} \quad$ : jarak antar air terminal

$p \quad$ : jarak penetrasi

$d_{\max A T} \quad$ :jarak maksimal antar air terminal 
Dari hasil perhitungan pada Tabel 4, diketahui pada masjid membutuhkan 4 air teminal dan gudang 6 air terminal. Namun, dalam perancangan menggunakan perangkat lunak AutoCad 2017 terlihat masih terdapat area gedung yang belum terproteksi karena perbedaan ketinggaian pada atap bangunan. Sehingga dibutuhkan penambahan jumlah air terminal yang harus dipasang. Masjid membutuhkan penambahan satu air terminal dan Gudang 3 air terminal. Berikut ini gambar perancangan pemasangan air terminal dan down conductor dengan metode rolling sphere:

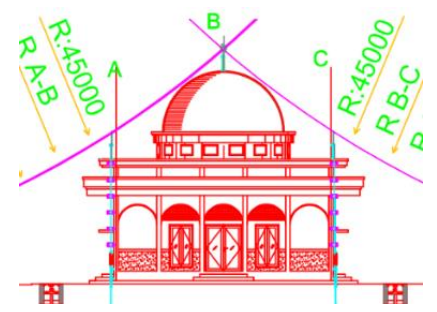

Gambar 3. Area perlindungan Metode Rolling Sphere pada Masjid Sisi Lebar

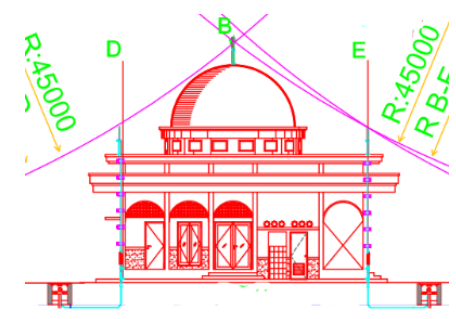

Gambar 4. Area perlindungan Metode Rolling Sphere pada Masjid Sisi Panjang

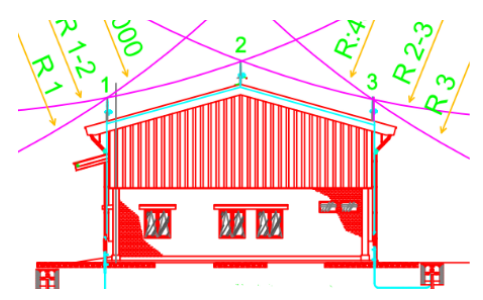

Gambar 5. Area perlindungan Metode Rolling Sphere pada Gudang Sisi Lebar

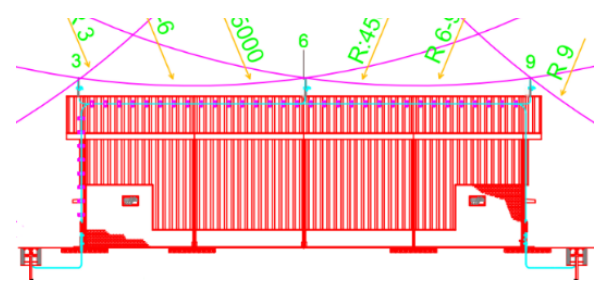

Gambar 6. Area perlindungan Metode Rolling Sphere pada Gudang Sisi Panjang

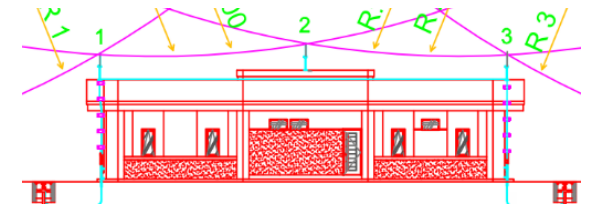

Gambar 7. Area perlindungan Metode Rolling Sphere pada Gedung Administrasi Sisi Lebar

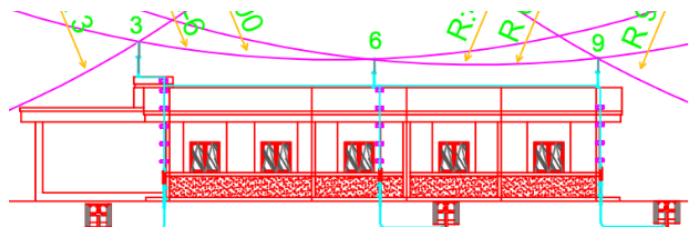

Gambar 8. Area perlindungan Metode Rolling Sphere pada Gedung Administrasi Sisi Panjang

Dari gambar 3, 4, 5, 6, 7 dan gambar 8, terlihat terdapat garis berwarna ungu yang merupakan garis khayal perlindungan rolling sphere, yang mana area dibawahnya merupakan area yang terlindungi. Dari gambar 3, 4, 5, 6, 7 dan gambar 8 terlihat bahwa seluruh area masjid, gudang dan gedung administrasi telah terlindungi dan telah memenuhi IEC 62305-3.

\subsection{Perancangan External Lightning Protection Dengan Metode Protection Angle}

Metode Protection Angle merupakan penyederhanaan dari metode rolling sphere berdasarkan IEC 62305-3. Sehingga penentuan tingkat proteksi serta perhitungan jumlah down conductor sama dengan jumah pada metode rolling sphere. Berikut ini hasil perancangan metode Protection Angle:

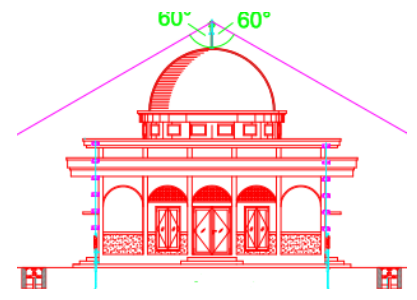

Gambar 9. Area perlindungan Metode Protection Angle pada Masjid Sisi Lebar

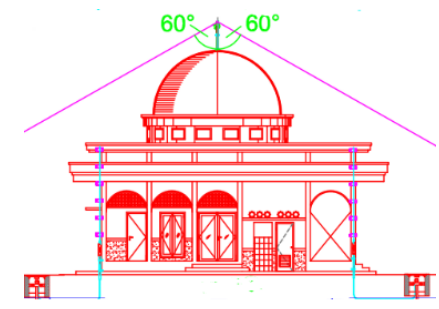

Gambar 10. Area perlindungan Metode Protection Angle pada Masjid Sisi Panjang 
Dari gambar 9 dan 10 terlihat, hasil perancangan metode protection angle pada masjid membutuhkan satu air terminal dengan jarak perlindungan 19,05 meter dan sudut perlindungan sebesar $60^{\circ}$, serta 4 buah down conductor dengan jarak 15 meter dapat melindungi seluruh bagian gedung dan telah memenuhi standar IEC 62305-3.

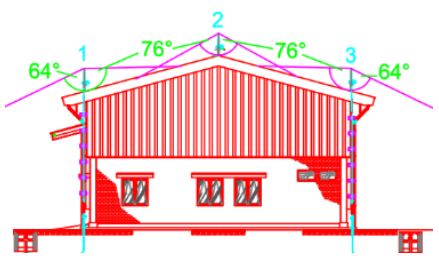

Gambar 11. Area perlindungan Metode Protection Angle pada Gudang Sisi Lebar

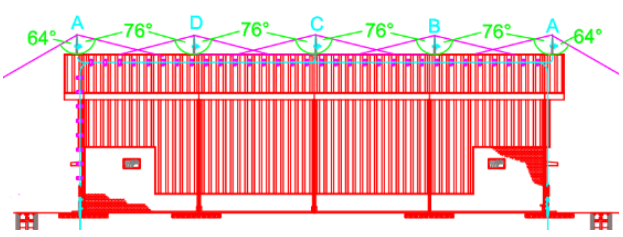

Gambar 12. Area perlindungan Metode Protection Angle pada Gudang Sisi Panjang

Dari gambar 11 dan 12 terlihat, hasil perancangan metode protection angle pada Gudang membutuhkan 15 buah air terminal, 10 air terminal dengan jarak perlindungan $16,4 \mathrm{~m}$ dan sudut perlindungan $64^{\circ}, 2$ air terminal dengan jarak perlindungan $17,32 \mathrm{~m}$ dan sudut perlindungan $60^{\circ}, 3$ air terminal dengan jarak perlindungan 4,01 meter dan sudut perlindungan $76^{\circ}$ serta 5 buah down conductor dengan jarak $15 \mathrm{~m}$ dapat melindungi seluruh bagian gedung dan telah memenuhi standar IEC 62305-3.

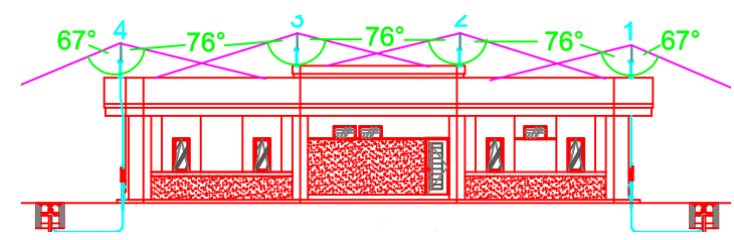

Gambar 13. Area perlindungan Metode Protection Angle pada Gedung Administrasi Sisi Lebar

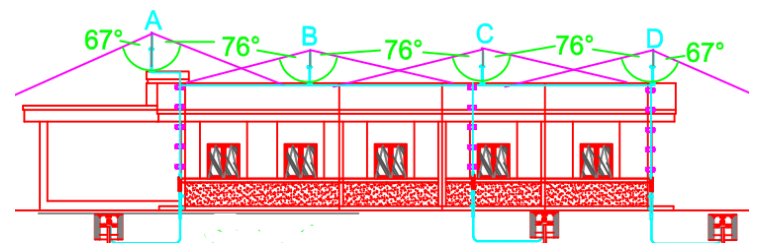

Gambar 14. Area perlindungan Metode Protection Angle pada Gedung Administrasi Sisi Panjang

Dari gambar 13 dan 14, terlihat hasil perancangan metode protection angle pada Gedung Administrasi membutuhkan 16 air terminal, 12 air terminal dengan jarak perlindungan $14,14 \mathrm{~m}$ dan sudut perlindungan $67^{\circ}, 4$ air terminal dengan jarak perlindungan 4,01 $\mathrm{m}$ dan sudut perlindungan $76^{\circ}$ serta 6 buah down conductor dengan jarak $15 \mathrm{~m}$ dapat melindungi seluruh bagian gedung dan telah memenuhi standar IEC 62305-3.

\subsection{Perancangan External Lightning Protection Dengan Metode Collecting Volume}

Metode Colecting Volume dilakukan berdasarkan IEEE998-2012 Standard .[8] Metode ini memiliki beberapa parameter dalam perhitungannya, yaitu :

a. Sudut Datang petir : sudut datang petir terhadap finial berkisar antara $0^{\circ}-60^{\circ}$ hal ini didasarkan bahwa besar sudut volume penangkapan maksimum terminal udara pada dasar teori adalah sebesar 52 $2^{\circ}$.[9]

b. Besar Arus petir : arus puncak petir secara umum di Indonesia terdistribusi normal dengan maksimum sambaran berkisar antara $18 \mathrm{kA}-50 \mathrm{kA}$ untuk sambaran jenis negatif dengan rata rata arus puncak petir sebesar $41 \mathrm{kA}$ dan untuk kecuraman arus (di/dt) sebesar 30 $\mathrm{kA} / \mu \mathrm{s}$. Menurut JADPEN tahun 1995 yang diukur pada daerah Subang Jawa-Barat. [10]

Tabel 5. Hasil Perhitungan dengan Metode Collecting Volume

\begin{tabular}{lcccc}
\hline \multicolumn{1}{c}{ Bangunan } & rs $(\mathbf{m})$ & $\Delta \max (\mathbf{m})$ & $\begin{array}{c}\text { Col. Volume } \\
\left(\mathbf{m}^{3}\right)\end{array}$ & $\boldsymbol{\theta}_{\mathbf{s}}\left(^{\circ}\right)$ \\
\hline Masjid & 94,9951 & 56,04711 & 677999,51 & $78,969^{\circ}$ \\
Gudang & 91,123 & 53,76257 & 612603,6443 & $80,131^{\circ}$ \\
Gedung & 80,798 & 47,67082 & 459222,6683 & $83,629^{\circ}$ \\
Administrasi & & & &
\end{tabular}

Keterangan :

$\mathrm{r}_{\mathrm{s}} \quad$ : jarak sambaran (m)

$\Delta \max \quad:$ maximum lateral displacement / attractive radius $(\mathrm{m})$

Col. Volume : Collecting Volume $\left(\mathrm{m}^{3}\right)$

$\theta_{\mathrm{s}} \quad:$ Sudut perlindungan $\left(^{\circ}\right)$

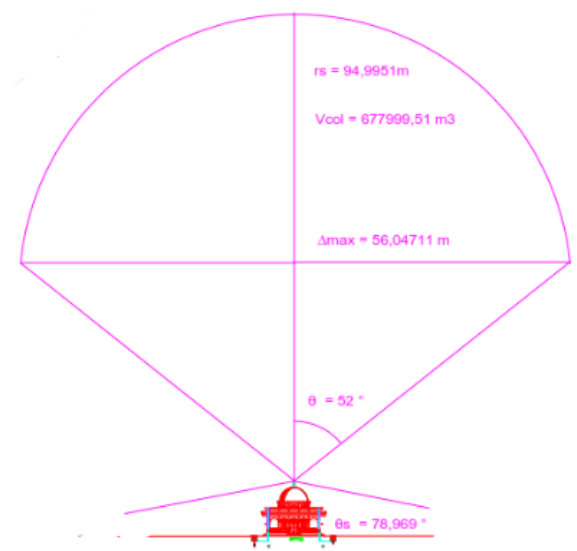

Gambar 15. Area perlindungan Metode Collecting Volume pada Masjid Sisi Lebar

Hasil perhitungan metode collecting volume pada Masjid membutuhkan 1 air terminal dengan sudut perlindungan $78,969^{\circ}$, collecting volume sebesar $677999,5 \mathrm{~m}^{3}$, dengan 
jarak sambaran 94,9951 m, maximum lateral displacement / attractive radius $(\Delta \max )=56,047 \mathrm{~m}$, pada arus puncak petir $50 \mathrm{kA}$ dan sudut kedatangan petir $\theta=0^{\circ}$ telah memenuhi IEEE998-2012 Standard.

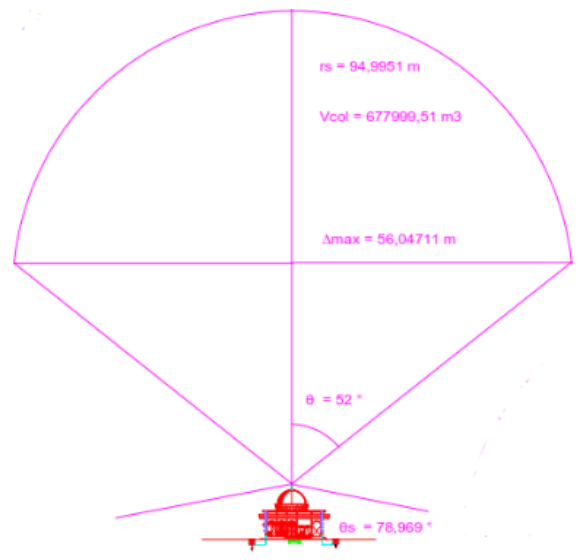

Gambar 16. Area perlindungan Metode Collecting Volume pada Masjid Sisi Panjang

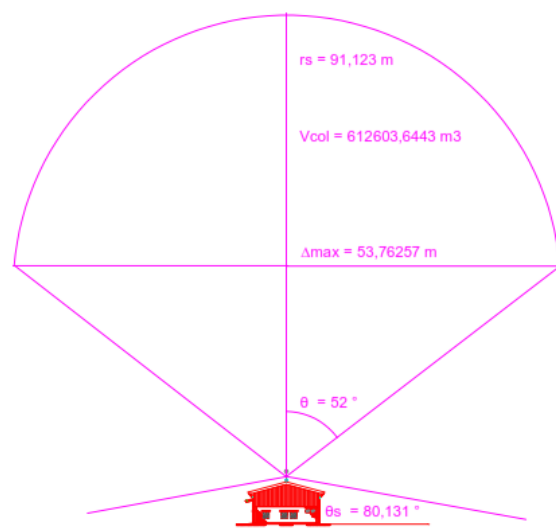

Gambar 17. Area perlindungan Metode Collecting Volume pada Gudang Sisi Lebar

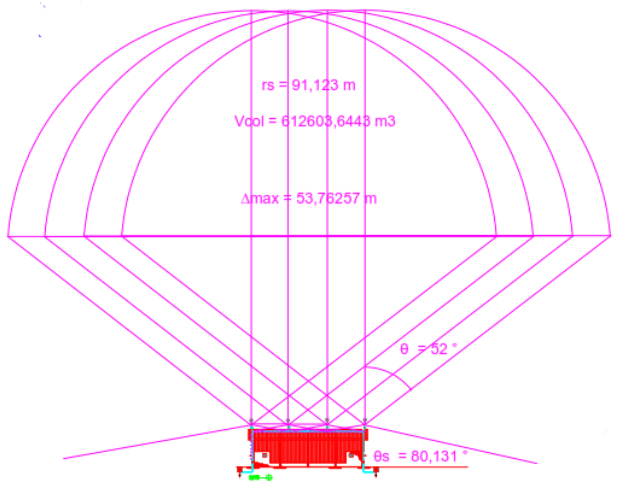

Gambar 18. Area perlindungan Metode Collecting Volume pada Gudang Sisi Panjang

Hasil perhitungan metode collecting volume pada Gedung Administrasi membutuhkan 1 air terminal dengan sudut perlindungan $80,131^{\circ}$, collecting volume nya sebesar $612603,6443 \mathrm{~m}^{3}$, dengan jarak sambaran 91,123 m, maximum lateral displacement / attractive radius $(\Delta \max )$ $=53,76257 \mathrm{~m}$, pada arus puncak petir $50 \mathrm{kA}$ dan sudut kedatangan petir $\theta=0^{\circ}$ telah memenuhi IEEE998-2012 Standard.

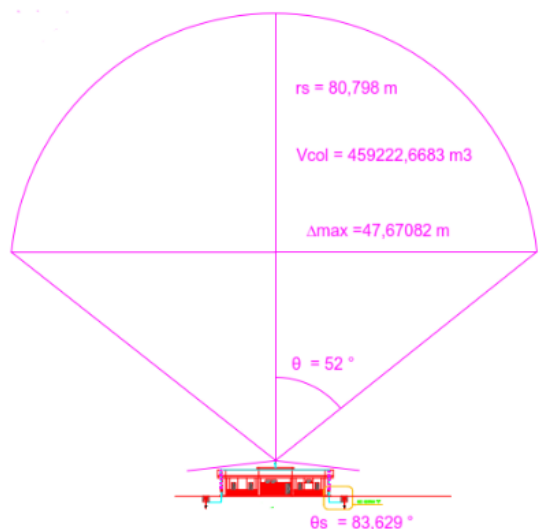

Gambar 19. Area perlindungan Metode Collecting Volume pada Gedung Administrasi Sisi Lebar

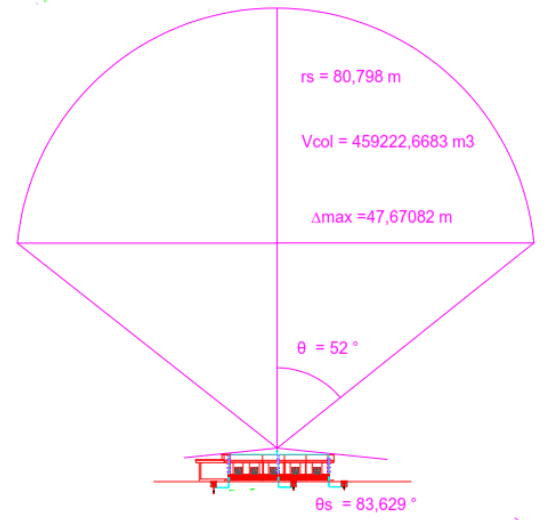

Gambar 20. Area perlindungan Metode Collecting Volume pada Gedung Administrasi Sisi Panjang

Hasil pehitungan metode collecting volume pada Gedung Administrasi membutuhkan satu air terminal dengan sudut perlindungan sebesar $83,629^{\circ}$, collecting volume nya sebesar 459222,6683 $\mathrm{m}^{3}$, dengan jarak sambaran 80,798 $\mathrm{m}$, maximum lateral displacement / attractive radius $(\Delta \max )=47,67082 \mathrm{~m}$, pada arus puncak petir $50 \mathrm{kA}$ dan sudut kedatangan petir $\theta=0^{\circ}$ telah memenuhi IEEE9982012 Standard.

\subsection{Perbandingan Metode Rolling Sphere, Protection Angle, dan Collecting Volume}

Setelah melakukan perancangan external lightning protection menggunakan metode Rolling Sphere, Protection Angle, dan Collecting Volume selanjutnya membandingkan area proteksi ketiganya. 


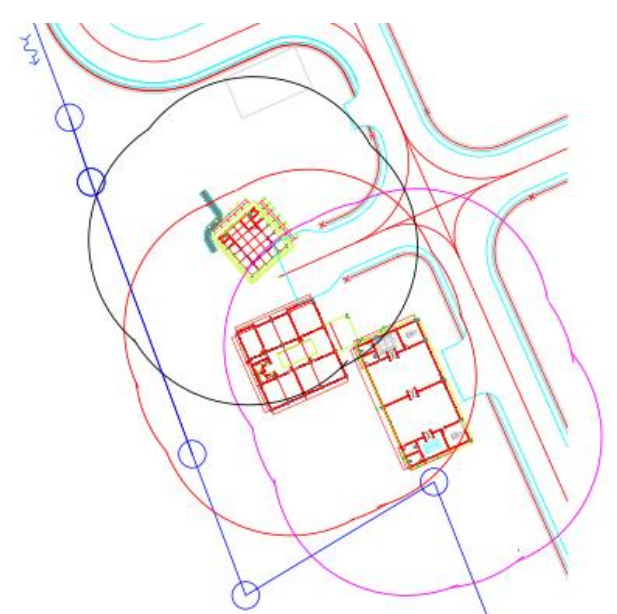

Gambar 21. Area Proteksi Metode Rolling Sphere

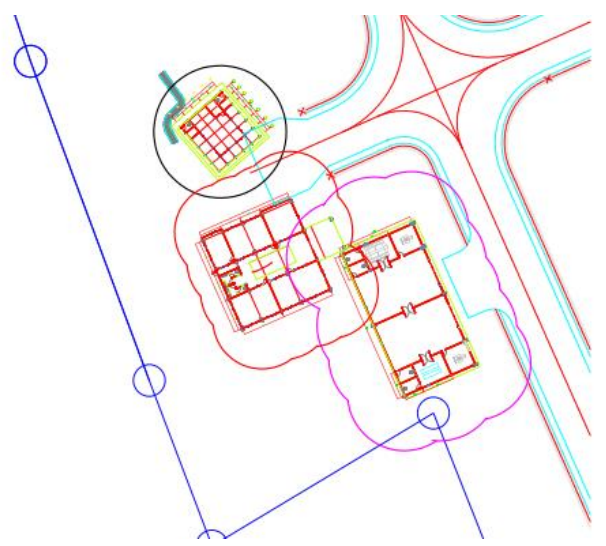

Gambar 22. Area Proteksi Metode Protection Angle

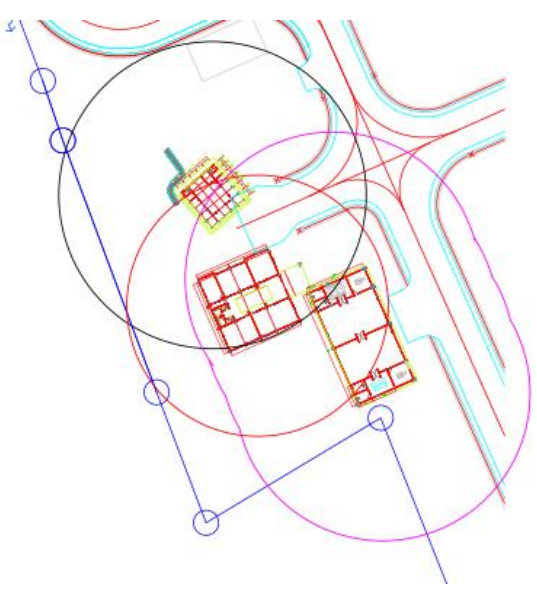

Gambar 23. Area Proteksi Metode Collecting Volume

Dari gambar 21, gambar 22, gambar 23 terlihat lingkaran warna hitam merupakan area proteksi masjid, lingkaran warna ungu merupakan area proteksi gudang, dan lingkaran warna merah merupakan area proteksi gedung administrasi.

\section{Kesimpulan}

Dari hasil Hasil penelitian, seluruh bagian gedung di komplek PLTG Gorontalo $100 \mathrm{MW}$ telah terlindungi dari sambaran petir langsung menggunakan external lightning protection dengan metode rolling sphere, protection angle dan collecting volume. Hasil perancangan metode rolling sphere dan protection angle menggunakan proteki level III telah memenuhi IEC 62305-3 dan dengan collecting volume telah memenuhi IEEE998-2012 Standard. Hasil perhitungan dan perancangan external lightning protection dengan metode rolling sphere, protection angle dan collecting volume terlihat metode collecting volume merupakan metode dengan area proteksi terluas dibanding lainnya.

Hasil perhitungan dan perancangan external lightning protection dengan metode rolling sphere, protection angle dan collecting volume terlihat metode collecting volume merupakan metode yang membutuhkan jumlah air terminal paling sedikit, yaitu yaitu satu air terminal pada masjid, 4 buah air terminal pada gudang, satu air terminal pada gedung administrasi, dibandingkan dengan metode rolling sphere, yaitu 5 buah air terminal pada masjid, 9 buah air terminal pada Gudang, 9 buah air terminal pada Gedung Administrasi, dan dengan metode protection angle, yaitu satu buah air terminal pada masjid, 15 buah air terminal pada gudang, 16 buah air terminal pada gedung administrasi.

Penggunaan metode collecting volume terbukti dapat meningkatkan efisiensi dari penggunaan air terminal yang dipasang pada bangunan tanpa mengurangi tingkat perlindungan. Selain itu, penggunaan metode collecting volume lebih detail dibanding dengan metode rolling sphere dan protection angle karena tiap area proteksinya tergantung dengan besarnya arus petir serta ketinggian posisi tiap air terminal yang dipasang berbeda dengan metode rolling sphere yang disamaratakan berdasarkan besarnya jari - jari kelas proteksi.

\section{Referensi}

[1] A. D. Hermawan, "Optimalisasi Sistem Penangkal Petir Eksternal Menggunakan Jenis Early Streamer," Universitas Indonesia, Depok, 2010.

[2] R. Zoro, "External Lightning Protection System for Main Office Building in the Area with High Lightning Density," Procedia Technol., vol. 11, no. Iceei, pp. 1238-1243, 2013.

[3] S. H. J. Tongkukut and B. M. Utara, "Identification of the Potential for Lightning Occurrence in North Sulawesi," Manado, 2008.

[4] J. Ginting, "ANALISA EFEK TEGANGAN INDUKSI KARENA SAMBARAN PETIR PADA AREA OPERASIONAL PT . X," Universitas Indonesia, 2012.

[5] R. Zoro, "Induksi dan Konduksi Gelombang Elektromagnetik Akibat Smbaran Petir pada Jaringan Tegangan rendah," Makara, Teknol., vol. 13, no. 1, pp. 25-32, 2009. 
[6] IEC, "IEC 62305-3 Protection against lightning - Part 3: Physical damage to structures and life hazard colour," 2010, $2.02010-1$.

[7] IEC, "IEC 1024-1-1 Protection of strucures against lightning," 1993

[8] IEEE, "IEEE Guide for Direct Lightning Stroke Shielding of Substations 998," 2012.

[9] N. I. Petrov, G. N. Petrov, and R. . Waters, "Determination of Attractive Area and Collection volume of Earthed Structure," 25th Int. Conf. Light. Prot., vol. 1, p. 2000, 2000.
[10] R. Veriyandi, Waluyo, and S. Saodah, "Perancangan Sistem Proteksi Petir Eksternal Menggunakan Metoda Collecting Volume pada Gudang TNT di PT Dahana ( Persero )," J. Reka Elkomika, vol. 2, no. 4, pp. 260-274, 2014.

[11] A. Syakur and Yuningtyastuti, "Sistem Proteksi Penangkal Petir Pada Gedung Widya Puraya," Transmisi, vol. 11, pp. 35-39, 2006.

[12] T. Suhartanto, Yuningtyastuti, and A. Syakur, "Penentuan Kebutuhan Proteksi Petir Pad Gedung Teknik Elektro Undip Dengan Adanya Bangunan Menara Base Transceiver Station," Semarang, 2005. 